\title{
Jak filosofovat o lidské mysli?
}

\author{
Jaroslav Peregrin \\ Filozofická fakulta \\ Univerzita Hradec Králové \\ Rokitanského 62, 50003 Hradec Králové \\ jaroslav.peregrin@uhk.cz
}

Ve své nové knížce Kauzalita činitele Petr Dvořák argumentuje, že svoboda vưle existuje, a tudíž musíme přijmout nějakou formu indeterminismu; a předkládá návrh odpovídajícího pojmového rámce. Já se naproti tomu domnívám, že ač svoboda vůle skutečně existuje, neměli bychom proto opouštět determinismus; hlásím se tedy k určité formě kompatibilismu. Podle mého druhu kompatibilismu tomu ovšem není tak, že by se svoboda vůle dala vtěsnat do deterministického rámce. Domnívám se, že řešení je v přijetí toho, že při výkladu skutečnosti nevystačíme s jediným pojmovým rámcem - konkrétně že na člověka se můžeme dívat jako na organismus (skrze deterministický a fyzikalistický rámec), ale také jako na osobu (skrze rámec, který je „prodchnut normativitou“).

Klícová slova: svoboda vůle, determinismus, indeterminismus, kompatibilismus, Sellars, Davidson, Kant, Petr Dvořák

\section{Kauzalita činitele}

Nová knížka Petra Dvořáka Kauzalita činitele ${ }^{1}$, jak píše její autor v úvodu, má být mimo jiné pokusem o to, aby mě autor přesvědčil „že dualistický koncept mysli do seriózní filosofie patří a že si odbornou diskusi zaslouží“. O tom mě asi přesvědčovat není třeba. Já si sice myslím, že dualismus karteziánského ražení úplně přijatelný není; nemyslím si ale, že by byl předem diskvalifikován ze seriózní filosofie. (Ve své knize ${ }^{2}$ píšu

1 Viz Dvořák (2020).

2 Viz Peregrin (2014). 
o „magických“ teoriích mysli, které podle mne diskvalifikovány jsou; určitě jsem ale nechtěl klást rovnítko mezi takové „magické“ pseudoteorie a dualismus.) To, co kolega Dvořák ve své knize předvádí, určitě seriózní filosofie je, dokonce bych řekl, že asi více než to, co předvádím já.

Petr Dvořák je scholastik, ovšem v nejlepším smyslu toho dnes poněkud pejorativně znějícího slova. Má-li pojednat o nějakém tématu, nastuduje si maximální možné množství literatury, všechno si v hlavě utřídí, zváží pro a proti. To, co o tom potom napíše, čtenáři zprostředkuje nejenom jeho vlastní příspěvek k tomuto tématu, ale i ucelený přehled o tom, co si o něm myslí jiní filosofové, a přehledné zdůvodnění, proč on nesouhlasí s těmi z nich, se kterými nesouhlasí. To je obdivuhodné.

Já sám toho také relativně hodně nastuduji, ale na rozdíl od Dvořáka nemám trpělivost se podrobně věnovat filosofům, jejichž názory jsou mimoběžné s těmi mými, nebo se kterými nesouhlasím. A i u těch, kteříjsou mi blízcí, mám tendenci se soustředit na nápady, které ve mně vyvolají větší či menší intelektuální rauš, a zbytku se věnovat jenom zběžně. To souvisí s mým (ne-scholastickým) přesvědčením, že filosofie musí mít za cíl takové intelektuální rauše - že nás má budit z dogmatických dřímot či nás, řečeno památnými slovy Richarda Rortyho, „vytahovat z našeho starého já silou podivnosti“33.

V úvodu své knihy Petr Dvořák nešetří na mou adresu komplimenty, píše o mé „schopnosti srozumitelné prezentace složitých myšlenek“. Jsem samozřejmě polichocen a jsem velmi rád, když někdo shledává to, co píšu, zajímavým či podnětným; mám ale obavu, že někdy se mé pokusy o filosofické provokace také míjejí účinkem a pak možná moc ke čtení nejsou. Abych ale vrátil lichotku: myslím, že to, co píše Petr Dvořák je - na rozdíl od toho, co píšu já - zajímavé i užitečné i pro ty, kdo s tím nesouhlasí.

\section{Indeterminismus?}

Pokud jde o svobodu vůle, stanoviska, která jsou zde k dispozici, můžeme roztřídit do tří dobře známých kategorií:

3 Rorty (1979, s. 360). 
1. Přijímáme determinismus, a tudíž odmítáme svobodu vůle.

2. Odmítáme determinismus, a tudíž můžeme přijmout svobodu vůle.

3. Přijímáme determinismus, ale i přesto přijímáme svobodu vůle (kterou vyložíme jako s determinismem slučitelnou).

Dvořák se domnívá, že svoboda vůle očividně existuje, a protože $s k u$ tečnou svobodu vůle nám může poskytnout jedině stanovisko kategorie 2., musíme se přiklonit k ní. Já s ním souhlasím v tom, že svoboda vůle očividně existuje: hraje v organizaci lidských společností, zejména v úvahách o tom, kdo za co může, tak zásadní roli, že popírat její existenci podle mne dost dobře nelze. Na rozdíl od Dvořáka si ale nemyslím, že bychom měli odmítnout determinismus, takže pro mne je jasná volba stanovisko kategorie 3.

Proč si myslím, že bychom neměli odmítat determinismus? Jeden důvod je docela zjevný: moderní věda nám předkládá deterministický obraz světa (pomineme-li kvantovou úroveň popisu, která je stále natolik enigmatická, že je asi lepší ji ponechat stranou). Ne že by věda byla posvátná kráva či že by se nemohla mýlit, ale je výsledkem systematické a dlouhodobé koncentrace úsilí nás lidí o poznávání světa, takže není úplně jasné, jak bychom mohli přijít s něčím, co by ji mohlo přebít. A žádný jiný tak systematický a tak komplexní popis světa, jaký nám podává věda, nemáme ( $\mathrm{k}$ tomu se ještě vrátím).

Je tu ale ještě jedna věc, která je $\mathrm{v}$ daném kontextu možná ještě podstatnější. Zdá se mi, že determinismus, jak nám ho servíruje moderní věda, již natolik ovládl i naše běžné uvažování, že vlastně už ani nedokážeme myslet nedeterministicky. Představme si, že sledujeme fotbalový zápas a že míč, který jeden z hráčů přihrál svému spoluhráči, najednou bez zjevného důvodu změnil směr. Proč se to stalo?, ptáme se. Odpovědí může být, že za to může nějaká nerovnost povrchu, po kterém se míč pohyboval. Nebo nějaký poryv větru. Nebo možná nějaká prapodivná faleš, kterou své přihrávce udělil přihrávající hráč. To všechno jsou více či méně přijatelná vysvětlení; ale představme si, že by nám někdo řekl, že ta změna směru neměla vůbec žádnou př́činu. Dokázali bychom se $\mathrm{s}$ tím spokojit? Dávalo by nám to vůbec nějaký smysl? Mně se zdá, že ne. 
Může se ovšem zdát, že indeterminismus, který potřebujeme, když chceme hájit svobodu vůle způsobem, jakým ji hájí třeba Dvořák, je jiného - a stravitelnějšího - druhu. Představa, že lidská bytost dokáže iniciovat nové kauzální řetězce, neboli způsobovat, že se stane něco, co nemá jinou prríčinu než rozhodnutí této bytosti, přece nezní vůbec nestravitelně!

Podívejme se ale na celou situaci podrobněji. Představme si nějakou konkrétní situaci, třeba že se někdo u soudu $\mathrm{z}$ vlastní vůle $\mathrm{k}$ něčemu přizná. To přiznání má podobu nějakých zvuků, které vypustí z úst. To vypuštění z úst je zjevně věcí nějaké činnosti „mluvidel“ tohoto člověka, která je zase vyvolána signály, které do nich přicházejí po nervových drahách z mozku. (Neurofyziologie by nám už dnes nepochybně dokázala $\mathrm{k}$ tomuto procesu dodat různé detaily.) Vyslání př́slušných signálů z mozku je ovšem zapříčiněno nějakými ději, které se v mozku odehrály předtím, a ty byly zase způsobeny nějakými předchozími událostmi, případně ději, které byly v mozku vyvolány něčím, co do něj přišlo po nervových drahách ze smyslů atd. A říci, že tady se najednou odehraje něco bez přičiny, mi připadá stejně nestravitelné, jako to říci o tom fotbalovém míči.

Indeterminista má zde tedy, zdá se mi, dvě možnosti. Jednak může říci, že „konatel“, který má schopnost iniciovat nové kauzální řetězce, se dokáže do sítě takových kauzálních řetězců, jaké neustále probíhají v našich mozcích, nějak „nabourat“ a způsobit, že se tam odehraje něco, co nemá standardní příčinu. To je ale věc, o které si nejsem jistý, jak píšu výše, že nám dává vůbec nějaký smysl. Anebo může odmítnout celý ten vědecký výklad toho, proč někdo vypustí z úst to, co vypustí - a i to mi z výše uvedených důvodů připadá nepřijatelné.

\section{Jazyky, kterými popisujeme svět}

Není to tedy neřešitelný spor? Dvořák má pocit, že jakákoli svoboda vůle, která by nerušila determinismus, není opravdová svoboda vůle; a já mám pocit, že determinismus nejde odmítnout ... (Když jsem se ještě živil programováním, existovalo pro takový bezvýchodný konflikt dvou programů takové pěkné slovo „deadlock“.) Inu, já mám pocit, že 
tak docela neřešitelný není, ale to je důsledkem některých názorů, které já mám na metody filosofie a které se mnou Dvořák asi nesdílí. V každém př́padě bude dobře, když ted' něco o těch svých názorech řeknu.

Zdá se mi, že Dvořák považuje to, zda je svět deterministický, či indeterministický, za čistě faktickou otázku, podobně jako třeba otázku, zda většinu země pokrývají oceány, či nikoli. Já jsem se naučil to vidět poněkud jinak: chápu to spíše jako otázku, jak daleko se v popisování světa dostaneme s jazykem, který má v sobě determinismus zabudovaný.

Podobně je to $\mathrm{s}$ fyzikalismem, který je druhou stránkou determinismu. Dvořák píše: „Domníváme se, že fyzikalismus neplatí v žádné verzi. “4 To je přesně ten druh prohlášení, se kterými já mám problém. Proč neplatí? Protože je fyzikalistický popis světa očividně chybný či neúplný? Zdá se mi, že at' už je chybný či neúplný, nebo ne, rozhodně to neplatí „očividně“; lidí, kteří fundovaně hájí fyzikalismus, je nemálo. Tak proto, že fyzikalistický popis nezachytí vše? Já mám problém s tím, co to tady znamená „vše“.

Někdo může třeba říkat, že nezachytí zázraky. No ale na to bude fyzikalista právě hrdý: zázraky podle něj prostě neexistují. Proč neexistují? Protože se nevejdou do fyzikalistického popisu světa. Ale tohle už vypadá jako př́pad přísloví Jednoho filosofa modus ponens je jiného modus tollens: fyzikalista ř́ká, že zázraky neexistují, protože se nevejdou do fyzikálního popisu světa, zatímco jeho odpưrce ř́ká, že fyzikalistický popis světa nemůže platit, protože se do něj nevejdou zázraky. Tím ovšem nechci ř́kat, že takové spory, jako je ten o zázraky, musejí vždy postrádat věcnou podstatu; jenom poukazuji na to, že vymezit ono „খše“, které se vejde nebo nevejde do fyzikalistického popisu světa, není neproblematické.

Kořeny tohoto mého postoje sahají až k vykřričenému „obratu k jazyku“, který v první polovině dvacátého století charakterizoval analytickou filosofii. ${ }^{5} \mathrm{U}$ něj jsem si uvědomil, že mnohé problémy, které se zdají týkat světa, jsou spíše problémy jazyka, kterým o světě hovoříme. Richard Rorty, který je pro mě představitelem toho, čemu já ř́kám „druhé kolo“ obratu k jazyku, ${ }^{6}$ mi pak pomohl pochopit, že vzhledem $\mathrm{k}$ tomu, že ne-

4 Dvořák (2020, s. 96).

5 Viz Rorty (1967). Viz též Peregrin (2005).

6 Viz Peregrin (1998). 
existuje žádný absolutně privilegovaný jazyk pro popis světa (tj. jazyk, který by nepř́islušel nám, ale jakoby tomu světu samotnému), je mnoho otázek o obecné povaze světa rozumné chápat jako otázky po použitelnosti různých jazyků k popisu světa.

Vrat’me se $\mathrm{k}$ determinismu: to je přesvědčení, že vše má svou příčinu. Ale zase: co je to „খše“? Vezměme třeba fakt, že je česká věta „Sníh je bílýc pravdivá. Čím je tohle zapřičiněno? Někdo může být v pokušení říci, že je to zapříčiněno faktem, že je sníh bílý. Pak by nám ale asi fyzika měla říct, jak k tomu zapříčinění dochází. To nám ale neřekne, protože fakt, že je nějaká věta pravdivá, není tím druhem faktu, s jakým by si věděla rady. ${ }^{7}$ Znamená to, že tento fakt nemá žádnou př́ičinu, a že tedy naplatí determinismus? To bychom neřekli, spíše bychom konstatovali, že determinismus se týká jenom těch faktů, se kterými si ví rady fyzika.

Zdá se mi, že naproti tomu otázka determinismu jako projekt, kam až se můžeme dostat $\mathrm{s}$ deterministickým popisem, je jasná a zajímavá. A moderní věda nám ukazuje, že se s ním dostaneme velmi velmi daleko - mně se zdá, že tak daleko, že prakticky není možné ten deterministický jazyk pominout. (Mějme ale na paměti, že to není proto, že by to byl nějak absolutně adekvátní jazyk, ale proto, že se fakticky ukazuje, že z hlediska své široké užitečnosti nemá moc vážnou konkurenci.)

Znamená to, že všechny ostatní jazyky lze do tohoto jazyka přeložit? Moderní věda tohle prokázala o mnohých jazycích, které dřive vypadaly jako více či méně autonomní. Rozhodně ale není důvod se domnívat, že to musí platit pro každý myslitelný a tak či onak zajímavý jazyk. A na jeden takový př́pad bych tady rád upozornil.

\section{„Vědecký obraz" a „zjevný obraz"}

Wilfrid Sellars ${ }^{8}$ nazývá to, co produkuje naše věda, vědeckým obrazem světa [,scientific image“]. Vědu má ve velké úctě; proslul dokonce svou variací na slavný Prótagorův výrok, které se začalo ř́́kat scientia mensura: „Věda je mírou všech věcí, jsoucích, že jsou, nejsoucích, že nejsou.“

7 Navzdory ojedinělým pokusům, jako je Field (1972), o zabudování pojmu pravdivosti do kauzálního řádu světa.

8 Sellars (1962). 
To znamená, že chceme-li autoritativní odpověd’ na otázku o tom, co je, musíme se s ní podle Sellarse obrátit na vědu.

Přesto si Sellars myslí, že tu je teorie, která není do vědeckého obrazu světa zabudovatelná a která je v některém ohledu možná i důležitější než vědecký obraz: hovoří o zjevném obrazu [„manifest image“]. Zjevný obraz je historicky původnější než ten vědecký; ten vědecký se zrodil $\mathrm{v}$ jeho lůně. A zjevný obraz obsahuje entity, které podle toho vědeckého neexistují. Sellars ř́ká, že to hlavní, co na něm najdeme, jsou osoby.

Znamená to tedy, že my lidé jsme do vědeckého obrazu nepronikli? Nikoli; samožrejmě, že tam jsme, ale jakožto organismy, které tak či onak fungují a tak či onak se chovají. Nejsme tam jako osoby, které konají činy, za které jsou pak také zodpovědné. Proč tomu tak je?

Sellars sám říká, že neredukovatelnost zjevného obrazu na vědecký obraz je věcí neredukovatelnosti „má být“ [„ought“] na „je“ [,„is“]. To naznačuje, že zjevný obraz není teorií ve stejném smyslu, v jakém jí je vědecký obraz - že nekonstatuje, co je, ale to, co být má. (Proto je také exkluzivním arbitrem toho, co je, vědecký obraz.)

Neplyne ale z toho, když přijmeme zjevný obraz, že přijímáme existenci osob? A není tohle něco, co popírá vědecký obraz, který je v tomto smyslu autoritou? A nemusíme tedy zjevný obraz z tohoto důvodu prostě odmítnout? Abychom vysvětlili, proč ne, musíme upozornit na nějaké jemné pojmové rozdíly. Představme si, že o někom řekneme třeba to, že je dlužník. Tím nekonstatujeme jenom fakta o tom, že si od někoho něco půjčil a dosud to nevrátil, konstatujeme i to, že to má vrátit. Takto chápaný dlužník tedy není ničím, co by mělo existovat ve smyslu vědeckého obrazu. Není to vůbec žádná věc, je to spíše role, do které můžeme různé věci (v tomto konkrétním př́padě lidské organismy) obsazovat. To, že má někdo něco vrátit, není vlastnost detekovatelná prŕírodovědecky. ${ }^{9}$

Tento Sellarsův názor ovšem není bezprecedentní. Domnívám se, že velmi podobné je Kantovo rozlišení mezi teoretickým a praktickým rozumem a zejména mezi jeho „ř́šíi pojmu přírody“ a „ř́iší pojmu svobody“. Je tu i paralela mezi touto Sellarsovou „stereoskopii“"10 a „anomálním

9 Protože $X$ má vrátit $Y 10$ ooo Kč není synonymní ani s Pokud $X$ nevrátí $Y 10$ ooo Kč, bude potrestán, ani s $X$ prohlásil, že Y vrátí 10 ooo Kč ani s ničím podobným.

10 Viz O’Shea (2012). 
monismem“ Donalda Davidsona ${ }^{11}$. (Dvořák se v knize podrobně věnuje zejména Davidsonově teorii jednání, jeho anomální monismus ale př́lilš netematizuje.)

\section{Kompatibilismus}

Tím se dostávám k oné specifické formě kompatibilismu, kterou já zastávám. Mám pocit, že svět dokážeme do velké míry velice dobře popsat deterministickým jazykem vědy. Zdá se mi, že by byl nesmysl se ho vzdávat, a taky se mi zdá, že ho nejde „vylepšovat“ tak, že by se na něj naroubovalo něco nedeterministického. Sem tam ale potřebujeme nějaký jiný druh popisu, zejména když chceme pojednat o smysluplných mezilidských vztazích, které jsou, řečeno se Sellarsem, „prodchnuty normativitou“ [,fraught with ought"]. Pak musíme to, co nám určitým způsobem popisuje věda, vyložit jiným způsobem - způsobem, který nám vyjeví to, co je pro nás podstatné.

Mám tedy pocit, že svět - včetně nás lidských bytostí jakožto organismů - je možné popisovat deterministickým jazykem vědy. (Beze zbytku? Na to nedokážu odpovědět, nebot mi není jasné, co vše se může počítat za ten zbytek - viz prŕklady se zázraky a s pravdivostí.) Tento jazyk vyhovuje určitému, já bych řekl základnímu, druhu porozumění, které my lidé hledáme. (Mohli bychom mu ř́kat „mechanistické“, ale tohle slovo si ve filosofii vysloužilo poněkud pejorativní přízvuk, což se mi nelíbí.) Pak tady ale mohou být ještě jiné druhy porozumění. Tak např́íklad Davidsonův anomální monismus se odvíjí od předpokladu, že porozumění jiným lidem, jak se k němu propracováváme během běžného obcování s nimi, je jiného druhu, než to vědecké - natolik jiného, že soustava pojmů, o které se opírá, je mimoběžná se soustavou pojmů, na kterých stojí věda.

Sellars navrhuje i vysvětlení, proč je tato soustava - jeho zjevný obraz - neredukovatelná na tu vědeckou. Je to podle něj proto, že to není teorie ve stejném smyslu, jako jsou ty vědecké. Je „prodchnuta normativitou“, což je dáno tím, že nesměřuje jenom k zachycení toho, co jak je, ale i k projekci našich vizí do budoucnosti: takhle to má být, takže bychom měli pracovat na tom, aby to tak $\mathrm{v}$ budoucnu bylo.

11 Viz Peregrin (2018). 
Jak už jsem psal, mám pocit, že tento pohled na tuto celou věc je velmi podobný tomu Kantovu. Jeho třetí antinomie z Kritiky čistého rozumu proti sobě staví Tezi

Kauzalita podle přírodních zákonů není jediná, z níž mohou být odvozeny veškeré jevy světa. $K$ jejich vysvětlení je nutno přijmout ještě kauzalitu prostřednictvím svobody.

\section{a Antitezi}

Žádná svoboda není, nýbrž vše ve světě se děje pouze podle přírodních zákonů. ${ }^{12}$

Terry Pinkard shrnuje Kantův vlastní postoj k této antinomii následujícím způsobem:

Nejslavnější z antinomií byla ta třetí, která tvrdila, že tu musí být radikální svoboda vůle, která zakládá kauzální řetězce, avšak sama není účinkem žádné jiné přičiny; a že každá událost musí mít příčinu, a svoboda tudíž nemůže existovat. To je ovšem podivné i podle Kantových vlastních měřítek. Transcendentální užití ostatních Idejí vede k antinomiím jako že svět má a nemá počátek v čase - ve kterých obě tvrzení postrádají jakoukoli kognitivní signifikanci. Avšak pokud jde o svobodu a determinismus, měl Kant za to, že musíme věrit jak tomu, že jsme bytosti ř́dící se zákony deterministicky chápaného vesmíru, tak že jsme radikálně svobodní a určujeme naše vlastní činy; oba prvky této antinomie jsou pravdivé. Ǩešením této antinomie, jak měl Kant argumentovat později, bylo, že z praktického hlediska se musíme považovat za noumenálně svobodné, ale z teoretického hlediska musíme být vzhledem k otázce svobody bud'to agnostičtí nebo tuto možnost zcela odmítnout. ${ }^{13}$

12 Kant (1781).

13 Pinkard (2002, s. 43). 
Způsob, jakým nám Dvořák ve své knize předvádí svět, v sobě z mého pohledu spojuje prvky sellarsovského zjevného i vědeckého obrazu či Kantova pohledu teoretické a praktické filosofie - je to heroický pokus o vybudování pojmového rámce pro jedinou všeobsahující teorii. Mně se ale zdá, že taková všeobsahující teorie nemůže existovat, z důvodů načrtnutých výše: naše úsilí o porozumění světu podle mne není jenom jedním projektem, ale propletencem více různorodých projektů, které se opírají o ne úplně slučitelné pojmové soustavy.

\section{Literatura}

Dvořák, P. (2020): Kauzalita činitele: Úvod do analytické diskuse o svobodě vưle. Togga, Praha.

Field, H. (1972): „Tarski’s theory of truth.“ The Journal of Philosophy 69 (15): 347-375.

Kant, I. (1781): Kritik der reinen Vernunft. Riga; český překlad Kritika čistého rozumu, OIKOYMENH, Praha, 2001.

O'Shea, J. R. (2012): „Prospects for a stereoscopic vision of our thinking nature: On Sellars, Brandom, and Millikan." HUMANA. MENTE 5 (21): 149-172.

Peregrin, J. (2005): Kapitoly z analytické filosofie. Filosofia, Praha. Peregrin, J. (2014): Jak jsme zkonstruovali svou vlastní mysl. Dokořán, Praha.

Peregrin, J. (2018): „Davidson and Sellars on ,Two Images““ Philosophia 46 (1): 183-192. https://doi.org/10.1007/s11406-017-9902-4.

Peregrin, J., ed. (1998): Obrat kjazyku: druhé kolo. Filosofia, Praha.

Pinkard, T. (2002): German Philosophy 1760-1860: the legacy of idealism. Cambridge University Press, Cambridge.

Rorty, R. (1979): Philosophy and the Mirror of Nature. Princeton University Press, Princeton.

Rorty, R., ed. (1967): The Linguistic Turn. The University of Chicago Press, Chicago. 
Sellars, W. (1962): „Philosophy and the Scientific Image of Man.“ In Frontiers of Science and Philosophy, ed. R. Colodny, University of Pittsburgh Press, Pittsburgh, s. 35-78.

\begin{abstract}
How to philosophize about human mind?

In his new book Petr Dvořák argues that freedom of will exists, and hence we must accept some form of indeterminism; and he presents a proposal of the corresponding conceptual framework. In contrast to this, I am convinced that though the freedom of will does exist, we should not abandon determinism; therefore I subscribe to a form of compatibilism. However, my version of compatibilism does not claim that freedom could be squeezed into the deterministic framework. I think that the solution consists in admitting that describing reality we do not make do with a single conceptual framework - specifically that a human individual can be seen as an organism (via the deterministic and physicalistic framework), but also as a person (via a framework that is "fraught with ought").
\end{abstract}

Key words: free will, determinism, indeterminism, compatibilism, Sellars, Davidson, Kant, Petr Dvořák

Peregrin, J. (2021): „Jak filosofovat o lidské mysli?“ Filosofie dnes 13 (1): 29-39. Dostupné z www.filosofiednes.ff.uhk.cz. 